\title{
Aplikasi Pencarian dan Penyewaan Rumah Kost Berbasis Web dan Android
}

\author{
Joysun Agape Sianturi, I Nyoman Piarsa, I Ketut Adi Purnawan \\ Program Studi Teknologi Informasi, Fakultas Teknik, Universitas Udayana \\ Bukit Jimbaran, Bali, Indonesia Telp. (0361) 701806 \\ e-mail: joysunagape@gmail.com, manpits@unud.ac.id, adipurnawan@unud.ac.id
}

\begin{abstract}
Abstrak
Kebutuhan rumah tinggal sementara seperti rumah kost yang semakin meningkat berbanding lurus dengan peningkatan pertumbuhan urbanisasi oleh pekerja di Indonesia. Pekerja yang mendapatkan pekerjaan di luar daerah harus mencari rumah kost pada area lokasi bekerja. Pencarian rumah kost yang ada pada masyarakat masih melakukan pencarian sederhana seperti datang ke lokasi untuk melihat langsung rumah kost. Pencarian dengan cara sederhada tersebut menyulitkan pencari melakukan pembandingan harga sewa, dan fasilitas karena harus datang ke lokasi rumah kost secara langsung. Permasalahan dalam mencari rumah kost tersenbut mendorong pembuatan aplikasi pencarian dan penyewaan rumah kost berbasis Web dan mobile Android dengan menggunakan metode penelitian terapan dengan diagram fishbone untuk menganalisis kebutuhan pencari dan pemilik rumah kost. Pencari terbantu dalam melakukan pencarian dan penyewaan rumah kost yang diinginkan dan pemilik terbantu dalam melakukan promosi rumah kost.
\end{abstract}

Kata kunci: Pencarian, Penyewaan, Rumah Kost, Website, Android

The need for temporary housing such as boarding houses that are increasing is directly proportional to the increase in urbanization growth by workers in Indonesia. Worker who get a job in outside area require worker to find a temporary housing such as boarding houses in the jobs area. The search for boarding houses in the community is still doing simple searches such as coming to the location of the boarding house to see the boarding house directly. The simple search makes it difficult for searchers to compare rental prices and facilities because they have to come to the boarding house location directly. Problems in finding boarding houses encourage the creation of application for searching and leasing boarding houses based on Web and Android mobile using applied research methods with fishbone diagrams to analyze the needs of searchers and boarding house owners. Boarding seekers are assisted in searching and renting the desired boarding house and the boarding house owner is helped in conducting boarding houses promotion.

Keywords: Search, Rental, Boarding House, Web, Android

1

Pendahuluan

Rumah kost menjadi suatu usaha yang bergerak di bidang jasa yang berpotensi karena semakin tinggi tingkat urbanisasi di Indonesia [1]. Rumah kost tersedia dalam berbagai jenis fasilitas dan harga yang ditetapkan. Semakin baik lokasi dan fasilitas sebuah rumah kost maka semakin tinggi harga sewa yang ditawarkan, sehingga menyulitkan para pencari yang berasal dari luar daerah untuk mengetahui harga yang tepat untuk sebuah kamar kost. Pencari yang berasal dari luar daerah terlambat dalam mendapatkan informasi daripada pencari yang telah mengenal baik lokasi tersebut dan keterlambatan dalam informasi tersebut menyebabkan keterlambatan dalam mendapatkan kost yang tepat.

Kemajuan teknologi yang semakin cepat membuat segala sesuatu serba cepat tidak terkecuali pencarian rumah kost karena kesibukan yang sangat tinggi. Mobile smartphone sangat membantu dalam memenuhi kebutuhan yang serba cepat tersebut karena dapat dibawa ke mana pun dan kapan pun. Aplikasi dirancang untuk pengguna mobile smartphone dengan basis Android dan mempermudah pengguna mencari rumah kost dengan cepat dan dapat 
diakses di mana saja dengan menggunakan koneksi internet. Pengguna dapat mengetahui lokasi dengan melihat pada peta digital dan melakukan penyewaan rumah kost.

Penelitian sebelumnya menggunakan peta digital untuk membantu menemukan tempat dan penelitian untuk melakukan pemesanan. Salah satu penelitian menggunakan peta digital yang berjudul "Tree Method Implementation in Geographic Information System of Pura Kawitan in Bali Based on Android Mobile" oleh Putu Resatya Andrian, I Nyoman Piarsa, dan Ni Kadek Ayu Wirdiani. Penelitan memperlihatkan lokasi pura yang di Bali dengan basis Android GIS menggunakan metode tree. Pura yang ditampilkan memiliki deskripsi dan gallery foto pura, dan navigasi ke lokasi pura [2]. Penelitan yang berjudul "The implementation of Tree Method in Geographic Information System of Mother Tample Mapping and its Linkages based on Web." oleh I Nyoman Piarsa, I Gede Udayana Putra, dan A.A. K. Sudana. Penelitan melakukan mapping pada pura yang terdapat di Bali. Penelitan menggunakan aplikasi berbasis Web untuk menampilkan peta lokasi dan data lokasi pura disimpan pada database sehingga membuat aplikasi berbentuk aplikasi hybrid dengan bantuan Google Map Api [3]. Penelitan yang membahas tentang penggunaan peta digital yaitu "Sistem Informasi Geografis Pemetaan Daerah Aliran Sungai Berbasis Web." oleh Sitta Rahayu, I Nyoman Piarsa, dan Putu Wira Buana. Penelitian menggunakan Web untuk menampilkan jaringan sungai, titik rawan banjir, panjang genangan banjir, berserta dengan deskripsi [4]. Penelitian tentang melakukan pemesanan menggunakan teknologi seperti penelitian yang berjudul "Rancang Bangun Aplikasi Sistem Pemesanan Bunga Berbasis Android" oleh Sri Ambar Pratiwi, I Made Sukarsa, I Ketut Adi Purnawan. Aplikasi yang dirancang adalah aplikasi untuk melakukan pemesanan bunga oleh masyarakat kepada pemilik toko bunga yang telah terdaftar ke sistem. Aplikasi menggunakan platform Android untuk memudahkan akses informasi toko bunga di manapun dengan menggunakan koneksi internet [5]. Penelitian yang dilakukan oleh Luh Gede Sri Handayani pada tahun 2015 yang berjudul "Sistem Informasi Geografis Pemetaan Jalan Desa Berbasis Web." Penelitian membahas tentang perancangan sistem untuk mencatat pemetaan jalan desa. Pemetaaan jalan desa menggunakan Google Maps, fitur polyline untuk menggambarkan sebuah jaringan jalan. Hasil dari penelitian adalah aplikasi yang menampilkan informasi kepada pengguna seperti nama jalan, panjang jalan, jenis permukaan jalan, dan kondisi jalan [6].

Penelitian terkait penggunaan peta digital untuk menampilkan sebuah lokasi yang memiliki koordinat latitude dan longitude dengan menggunakan peta digital pada basis Web. Peta digital yang digunakan dalam mencari lokasi dapat kemudian diterapkan dalam mencari rumah kost. Aplikasi Pencarian dan Penyewaan Rumah Kost Berbasis Web dan Android mampu membantu masyarakat dalam melakukan pencarian menggunakan peta digital untuk memudahkan pencarian lokasi dan pemberian deskripsi informasi seperti fasilitas, lokasi, dan harga sewa untuk membantu pencari dalam memilih dan menyewa rumah kost yang dapat diakses di manapun dan kapan pun dengan koneksi internet.

\section{$2 \quad$ Metode Penelitian}

Metode Penelitian menggunakan metode terapan. Metode penelitian terapan adalah penelitian yang diarahkan untuk mendapatkan informasi yang dapat digunakan untuk memecahkan masalah dengan tujuan menerapkan, menguji, dan mengevaluasi masalah yang praktis [7]

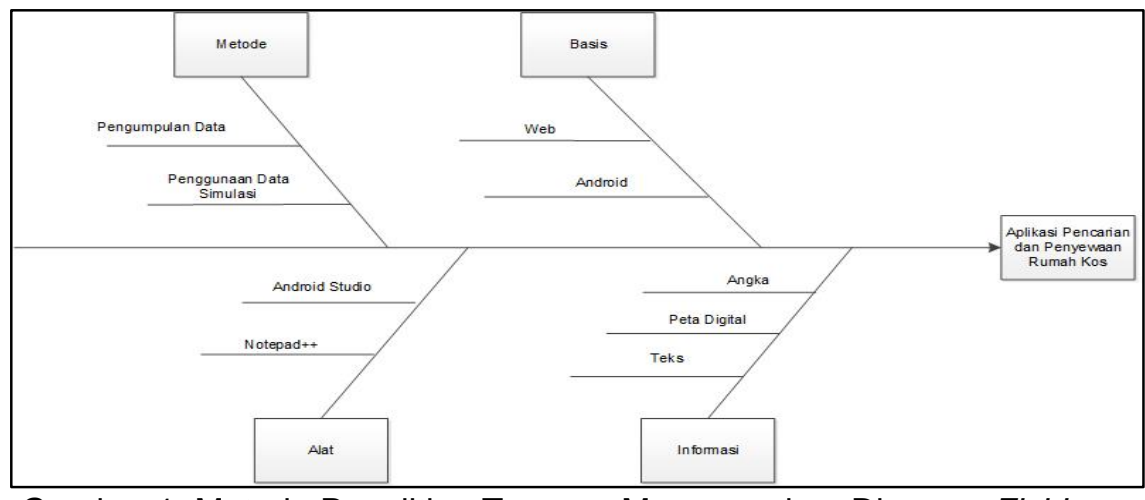

Gambar 1. Metode Penelitian Terapan Menggunakan Diagram Fishbone 
Gambar 1 merupakan diagram fishbone yang digunakan untuk mengidentifikasi berbagai sebab potensial dari satu efek atau masalah, dan menganalisis masalah tersebut untuk membuat sebuah rancangan sistem yang dapat mengatasi masalah yang ada. Masalah dipecah menjadi sejumlah kategori yang berkaitan. Kategori metode untuk melakukan indentifikasi dengan melakukan pengumpulan data seperti masalah yang ada masyarakat dalam mencari rumah kost, dan sebagainya untuk dapat menyusun sistem yang tepat. Sistem yang di susun berdasarkan data yang telah dikumpulkan kemudian disimulasikan. Alat merupakan peralatan yang digunakan dalam mebangun aplikasi seperti notepad++ untuk membuat aplikasi berbasis web menggunakan bahasa PHP(Hypertext Prepocessor) dan aplikasi Android Studio untuk membuat aplikasi berbasis mobile Android menggunakan bahasa pemrograman Java. Kategori basis untuk menentukan basis pembuatan aplikasi yaitu Web dan mobile Android. Informasi adalah data yang disimpan dalam aplikasi bersifat text, angka, dan peta digital.

\subsection{Gambaran Umum}

Aplikasi menawarkan jasa pencarian berbasis Android dan Web untuk memudahkan pemilik dalam hal mempromosikan rumah kost untuk dapat dilihat oleh banyak orang dan pencari dalam mencari lokasi serta mengetahui detail tentang informasi seperti harga, fasilitas dari rumah kost.

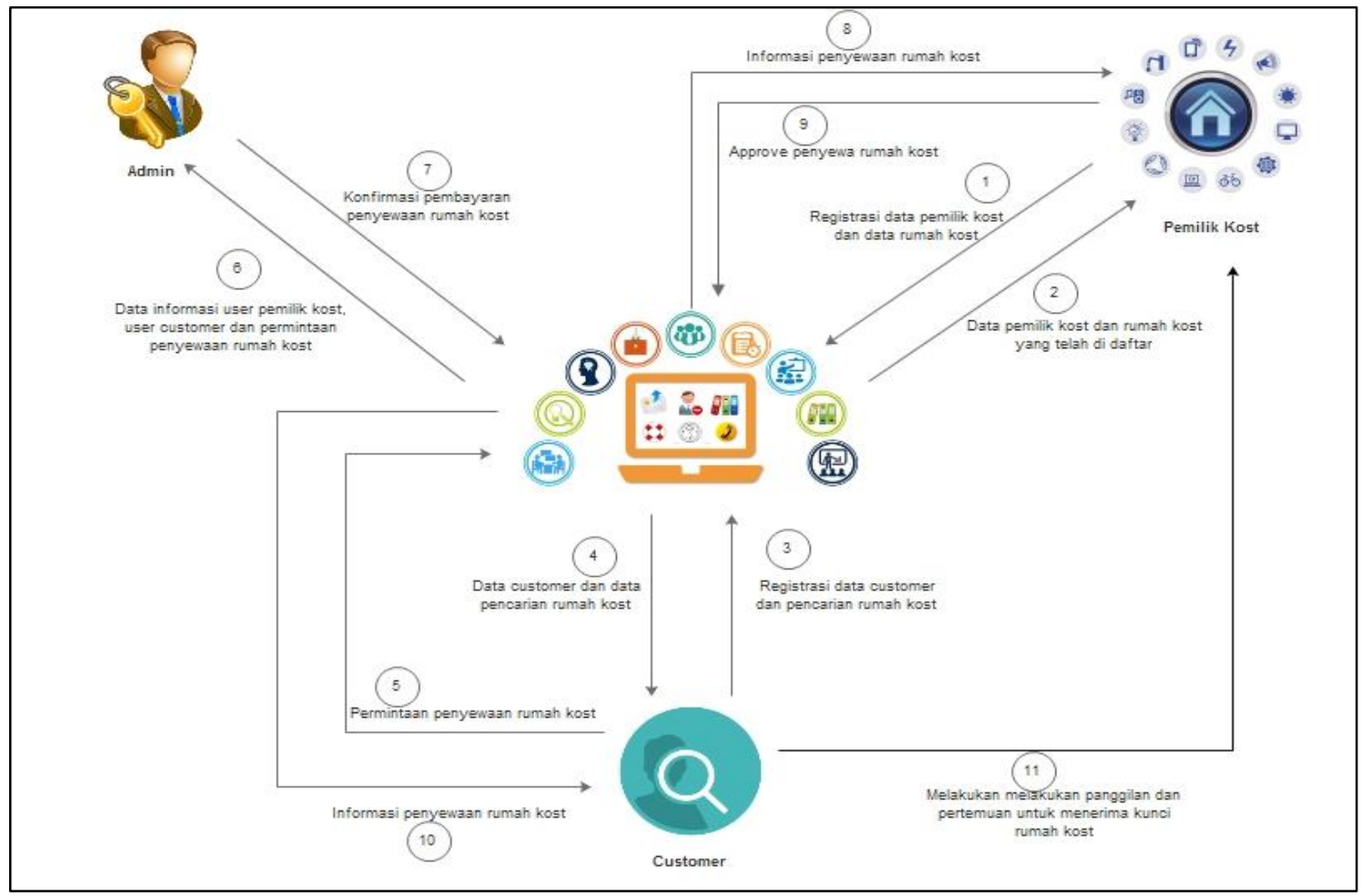

Gambar 2. Gambaran Umum Sistem

Gambaran umum sistem pada Gambar 2 di mulai dari pemilik melakukan registrasi akun dan mendaftarkan informasi tentang rumah kost. Customer dapat melakukan registrasi dan login untuk kemudian dapat melakukan pencarian rumah kost dan melakukan penyewaan rumah kost. Penyewaan rumah kost dilakukan pengecekan oleh admin sistem. Transaksi penyewaan rumah kost yang telah di validasi kemudian dapat dilakukan approve oleh pemilik. Pemilik melakukan approve penyewaan dan customer mendapatkan data transaksi penyewaan telah di approve atau tidak. Customer dapat melakukan upload data diri dan dapat melakukan pertemuan untuk pemberian kunci rumah kost. 


\subsection{Activity Diagram}

Activity diagram adalah adalah bahasa spesifikasi standar yang dipergunakan untuk mendokumentasikan, menspesifikasikan dan membanngun perangkat lunak [8].

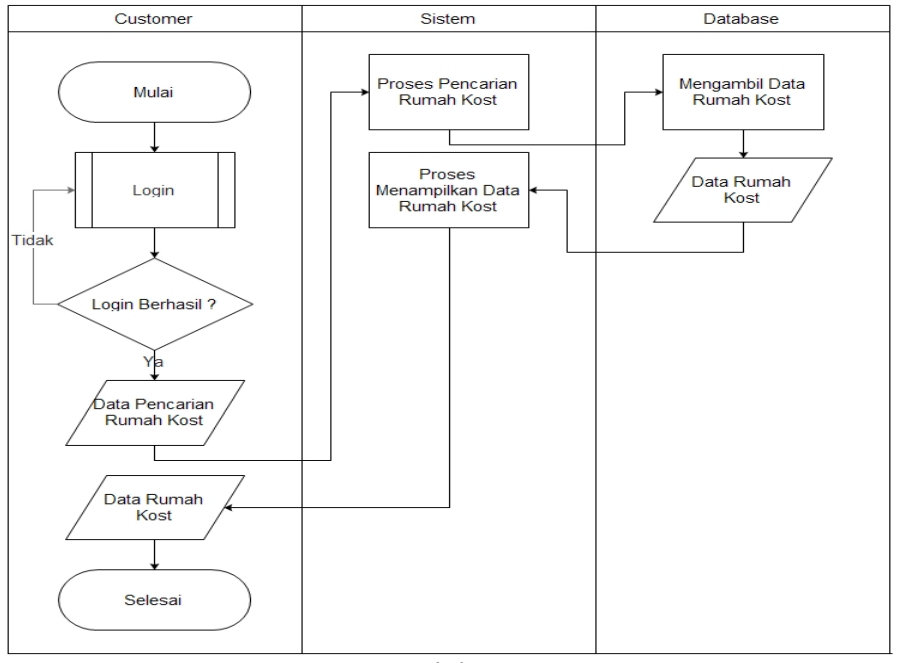

(a)

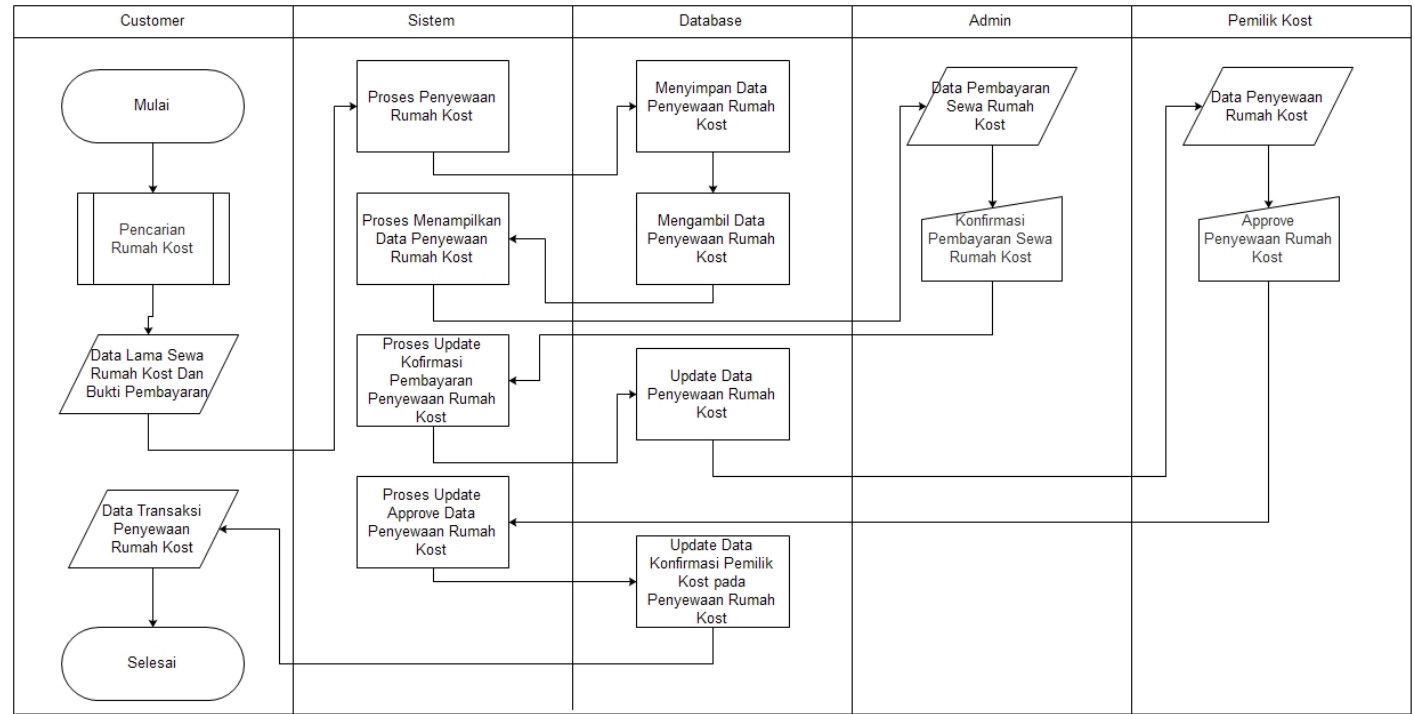

(b)

Gambar 3. (a) Activity Diagram Pencarian Rumah Kost

(b) Activity Diagram Penyewaan Rumah Kost

Gambar 3 merupakan alur pencarian dan penyewaan rumah kost. Customer terlebih dahulu melakukan login, dan melakukan pencarian rumah kost yang diinginkan, kemudian melakukan penyewaan dan memberikan bukti transfer biaya sewa rumah kost. Admin melakukan validasi terhadap transaksi pembayaran yang dilakukan customer. Pembayaran yang telah di validasi dapat dilakukan approve oleh pemilik untuk customer dapat menempati rumah kost.

\subsection{Struktur Database}

Rancangan database berisi tabel yang berkaitan membentuk hubungan yang saling berkaitan pada sistem informasi pencarian dan penyewaan rumah kost berbasis Web dan Android. 


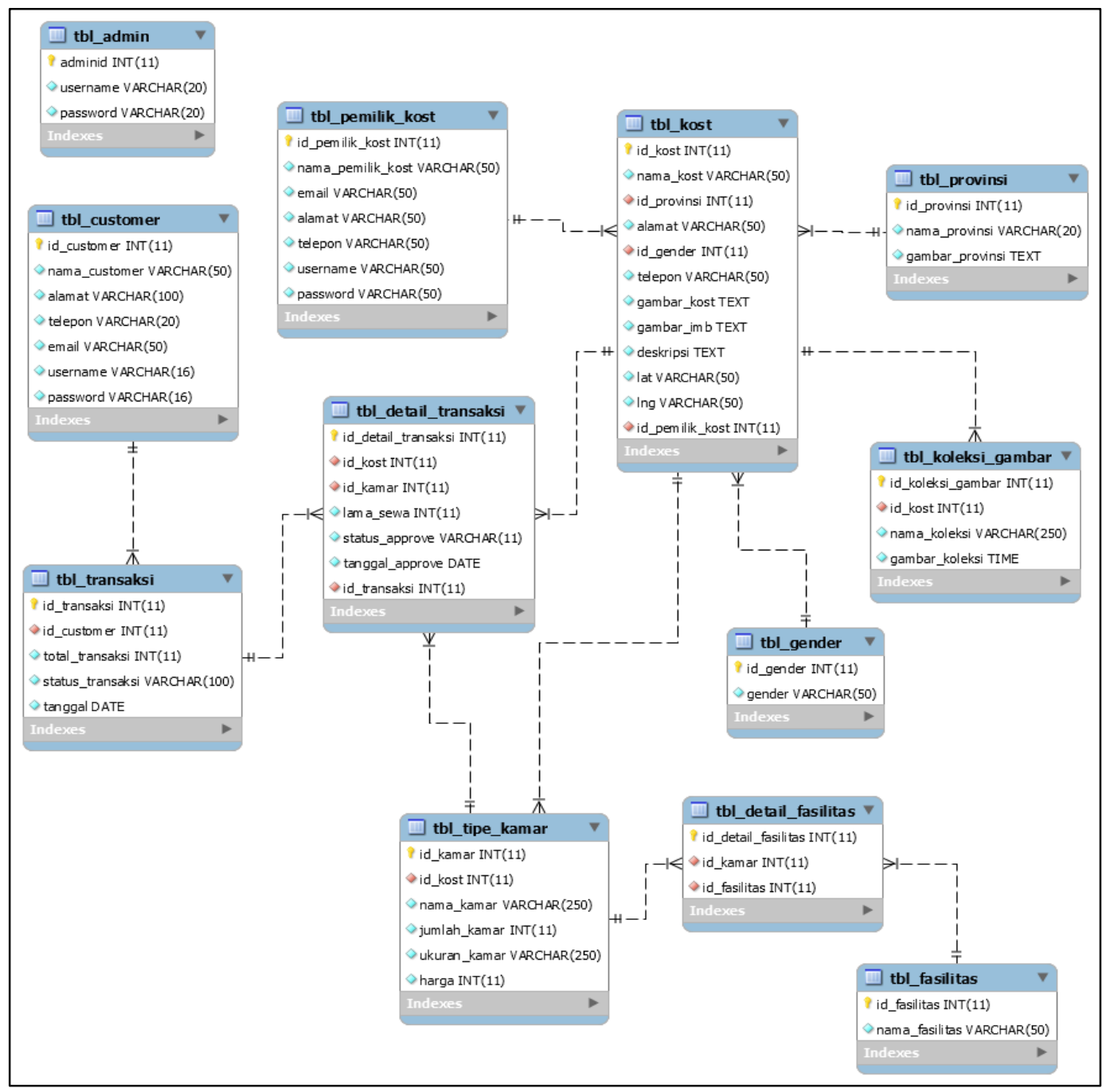

Gambar 4. Database Sistem

Gambar 4 merupakan relasi antar tabel pada aplikasi pencarian dan penyewaan rumah kost berbasis Web dan Android. Tabel admin digunakan admin sistem untuk mengelola sistem seperti melakukan manage user dan transaksi. Tabel tbl_customer digunakan untuk menyimpan data customer. Tabel tbl_pemilik_kost digunakan untuk menyimpan data pemilik. Tabel tbl_kost untuk menyimpan data rumah kost. Tabel tbl_provinsi digunakan untuk meyimpan data provinsi. Tabel tbl_gender untuk menyimpan data gender yang dapat menempati seperti rumah kost khusus untuk pria, atau khusus wanita. Tabel tbl_room digunakan untuk menyimpan data tipe kamar rumah kost. Tipe kamar berfungsi untuk menampilkan rumah kost yang memiliki tipe kamar yang berbeda-beda dan fasilitas yang berbeda pada setiap tipe kamar. Tabel tbl_detail_fasilitas adalah tabel yang menggabungkan relasi antara tipe kamar dan fasilitas yang bertujuan membuat sebuah rumah kost dapat memiliki banyak tipe kamar dengan fasilitas yang berbeda. Tabel tbl_transaksi berelasi dengan tabel tbl_kost dan customer untuk menampilkan transaksi penyewaan dari customer. Tabel tbl_detail_transaksi berelasi dengan tbl_kost, tbl_tipe_kamar, dan tbl_transaksi digunakan untuk menyimpan data detail transaksi penyewaan rumah kost Tabel pajak menampilkan jumlah pajak yang digunakan. Tabel tb_kost berelasi dengan tabel tb_provinsi untuk menampilkan rumah kost berdasarkan provinsi.

\subsection{Perancangan Use Case Diagram}

Use case diagram merupakan penjabaran dari Actors dan kebutuhan fungsi use case yang diperlukan di dalam sistem. Pemodelan sistem aplikasi menggunakan use case diagram sebagai dapat di lihat pada Gambar 5. 


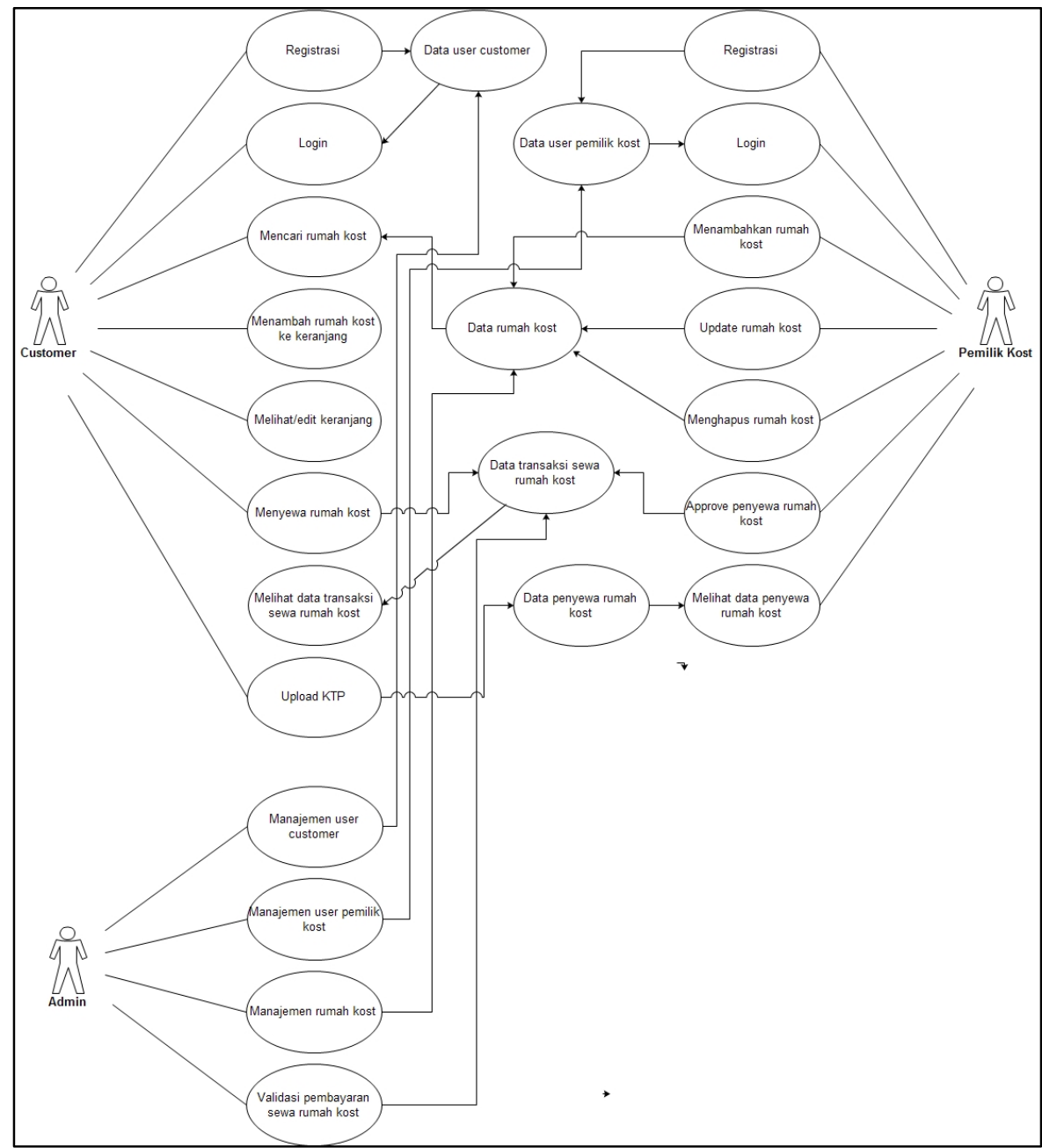

Gambar 5. Use Case Diagram Sistem

Gambar 5 merupakan usecase diagram sistem. Sistem aplikasi memiliki tiga aktor yaitu admin, customer, dan pemilik. Admin memiliki hak untuk melakukan manage user dan rumah kost, dan melakukan validasi data transaksi pembayaran sewa. Customer memiliki hak akses untuk melihat daftar rumah kost, menyewa menyewa rumah kost, melihat data traksaksi penyewaan rumah kost yang pernah dilakukan dan melakukan upload indentitas diri, sedangkan pemilik memiliki akses untuk mendaftar rumah kost, melakukan update terhadap rumah kost, menghapus rumah kost, dan melakukan approve terhadap transaksi penyewaan rumah kost oleh customer.

\section{$3 \quad$ Kajian Pustaka}

Kajian memaparkan mengenai teori-teori yang dijadikan penunjang dalam pembuatan sistem pencarian dan penyewaan rumah kost.

\subsection{Rumah Kost}

Rumah adalah sebuah tempat yang menawarkan jasa tempat untuk ditinggali dengan sejumlah pembayaran pada setiap periode tertentu. Kata indekost diserap dari frasa bahasa Belanda In de kost. Defenisi in de kost adalah makan di dalam, tetapi bila dijabarkan lebih lanjut dapat pula berarti tinggal dan ikut makan di dalam rumah tempat menumpang tinggal. Seiring dengan perubahan zaman, sekarang khalayak umum di Indonesia menyebut istilah indekost dengan kost [9]. 


\subsection{PHP(Hypertext Prepocessor)}

PHP adalah bahasa server-side -scripting yang menyatu dengan HTML untuk membuat halaman web yang dinamis. Karena PHP merupakan server-side-scripting maka sintaks dan perintah-perintah PHP diesksekusi diserver kemudian dikirimkan ke browser dengan format HTML [10].

\subsection{GIS (Geographic Information System)}

GIS adalah suatu komponen yang terdiri dari perangkat keras, perangkat lunak, data geografis dan sumber daya manusia yang bekerja bersama secara efektif untuk memasukan, menyimpan, memperbaiki, memperbaharui, mengelola, memanipulasi, mengintegrasikan, menganalisa dan menampilkan data dalam informasi berbasis geografis. SIG merupakan salah satu sistem informasi. SIG merupakan suatu sistem yang menekankan pada unsur informasi geografi. Istilah "geografis" merupakan bagian dari spasial (keruangan). Kedua istilah ini sering digunakan secara bergantian atau tertukar hingga timbul istilah yang ketiga, geospasial [11].

\subsection{Java}

Java merupakan bahasa berorientasi objek untuk pengembangan aplikasi mandiri, aplikasi berbasis internet, aplikasi untuk perangkat cerdas yang dapat berkomunikasi lewat internet/jaringan komunikasi. Teknologi java memungkinkan perangkat audio streo dirumah terhubung jaringan komputer. Java tidak hanya untuk membuat applet yang memperintah halaman web tapi java telah menjadi bahasa untuk pengembangan aplikasi skala interprise berbasis jaringan besar [12].

\section{$4 \quad$ Hasil dan Pembahasan}

Hasil dari penelitian merupakan aplikasi yang berfungsi untuk melakukan pencarian dan penyewaan rumah kost dengan menggunakan basis Web dan mobile Android. pemilik dapat menambahkan rumah kost menggunakan aplikasi basis Web dan customer menggunakan aplikasi mobile Android dalam mencari dan menyewa rumah kost

\subsection{Pemilik Rumah Kost}

Aplikasi pencarian dan penyewaan rumah kost berbasis web dan mobile Android. Pemilik dalam mendaftarkan rumah kost menggunakan marker peta digital menggunakan Google Maps untuk mendapatkan lokasi berdasarkan latitude dan longitude. Rumah kost yang didaftarkan memiliki informasi tentang nama, alamat, gender khusus yang dapat menempati rumah kost, nomor telepon, tipe kamar, dan deskripsi. Tampilan penambahan rumah kost dapat dilihat pada Gambar 6. 


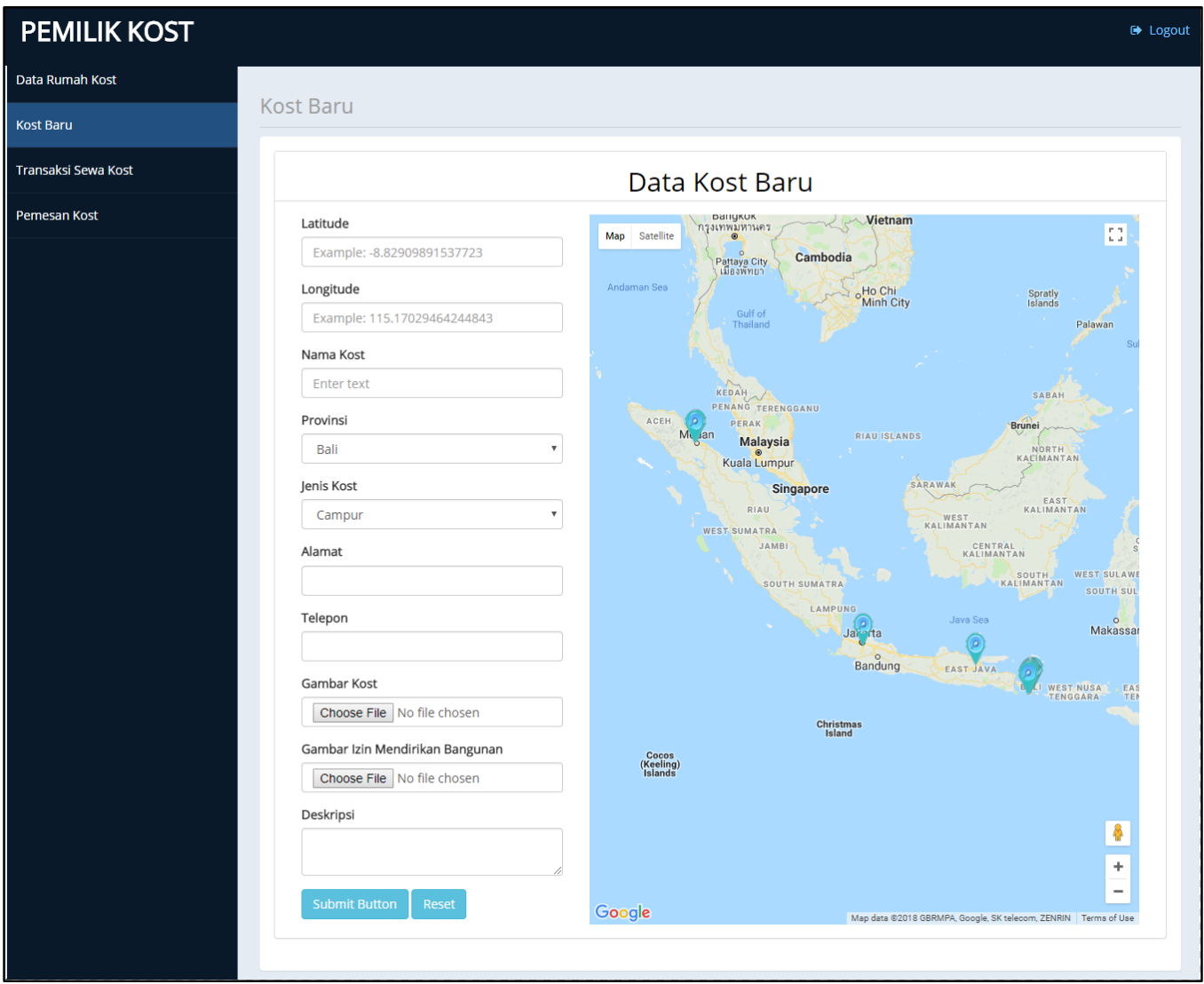

Gambar 6. Tampilan Halaman Penambahan Rumah Kost

Gambar 6 merupakan tampilan panel pemilik menambahkan rumah kost dengan melakukan marker pada peta digital, kemudian latitude dan longitude dari marker otomatis ditampilkan beserta dengan alamat, pemilik kemudian melakukan input pada nama, alamat, provinsi, gender yang dapat menempati rumah kost, nomor telepon, photo tampilan rumah kost, foto scan Izin Mendirikan Bangunan (IMB), dan deskripsi. Rumah kost yang telah di tambahkan kemudian dapat menambahkan tipe kamar. Tampilan halaman penambahan tipe kamar rumah kost dapat dilihat pada Gambar 7.

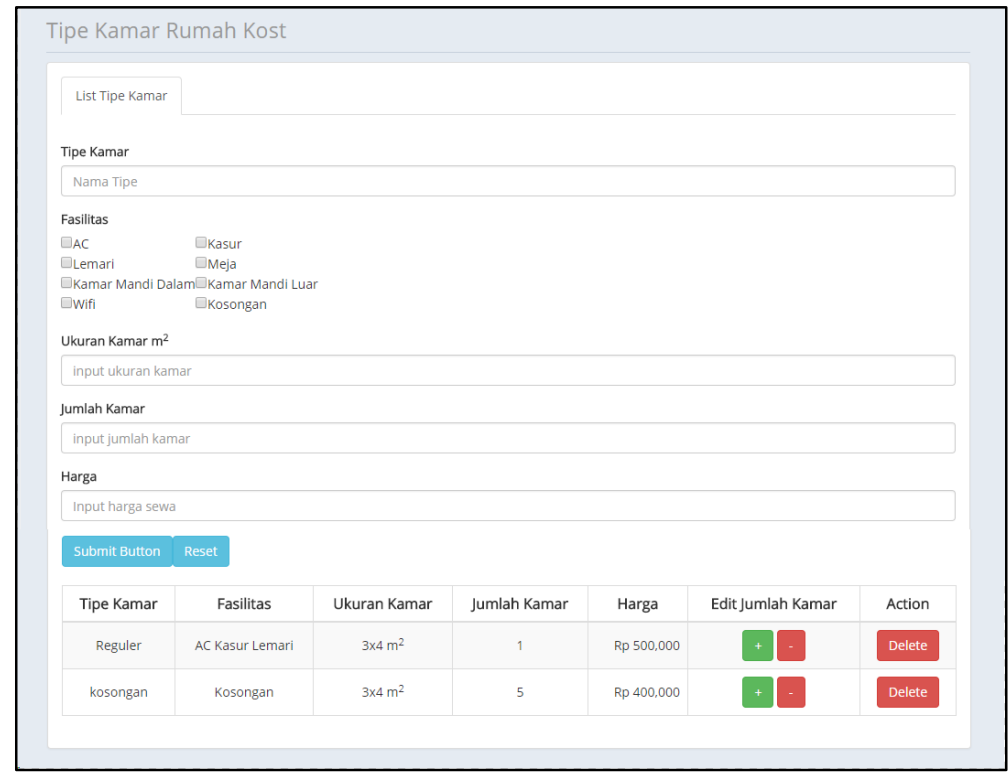

Gambar 7. Tampilan Halaman Tipe Kamar Kost 
Gambar 7 merupakan tampilan pemilik yang telah menambahkan rumah kost dan dapat melakukan penambahan tipe kamar yang dimiliki. Tipe kamar yang ditambahkan memiliki deskripsi seperti nama tipe kost, fasilitas yang tersedia, ukuran kamar, dan harga sewa. Rumah kost yang disewa oleh customer dilakukan approve oleh pemilik seperti pada Gambar 8.

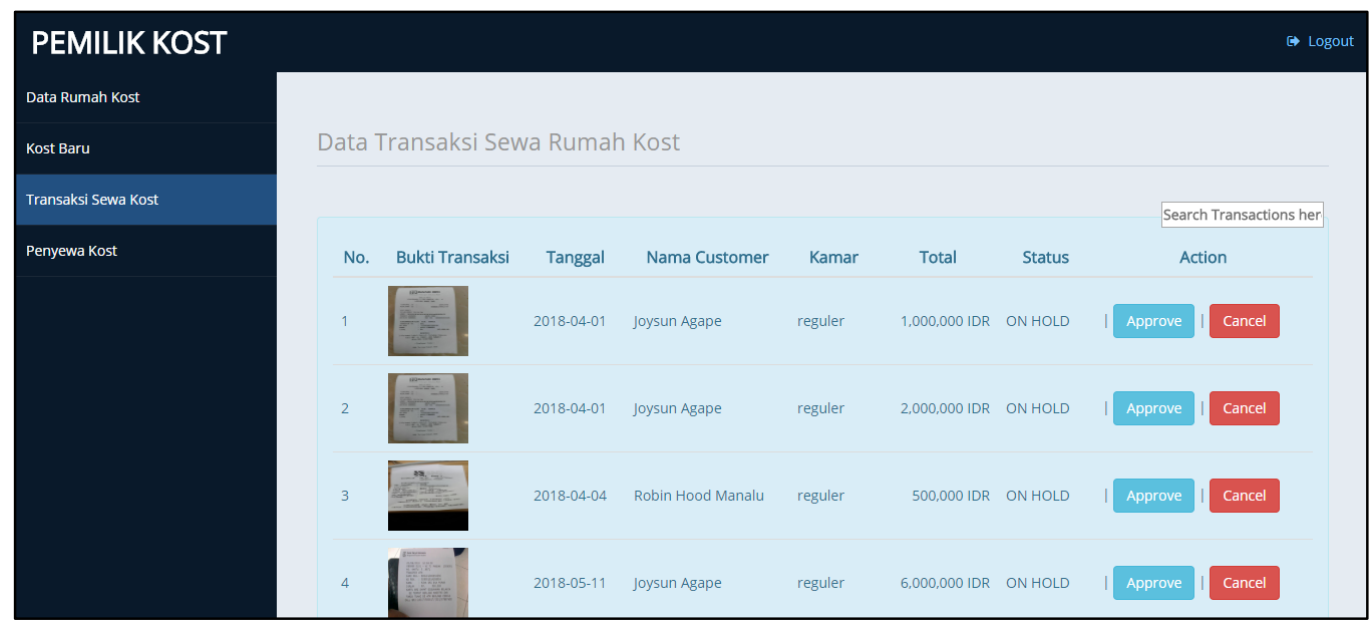

Gambar 8.Panel Approve Transaksi Sewa oleh Pemilik Rumah Kost

Gambar 8 merupakan tampilan halaman panel pemilik melakukan approve bertujuan untuk menghindari kesalahan pemilik yang lupa dalam melakukan update data rumah kost yang ternyata telah ditempati oleh orang lain tanpa menggunakan aplikasi. Penyewaan yang telah dilakukan approve mengubah status "ON HOLD" menjadi "Confirm",

\subsection{Customer}

Customer sebagai pencari dapat melakukan pencarian rumah kost menggunakan mobile Android. pencarian Rumah kost dapat dilihat pada Gambar 9.

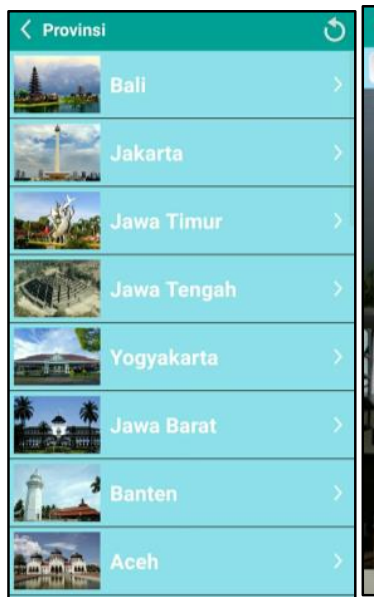

(a)

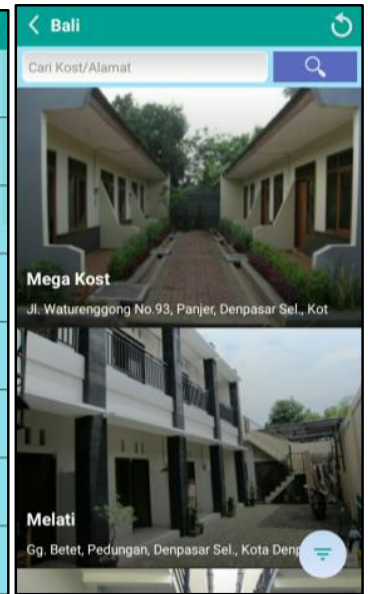

(b)

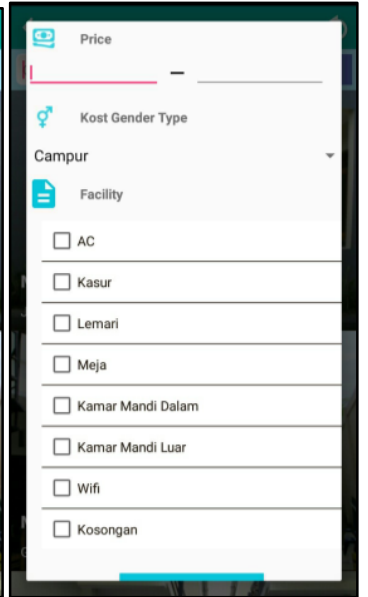

(c)

Gambar 9.(a) tampilan pencarian berdasarkan provinsi.

(b) tampilan rumah kost berdasarkan pencarian provinsi

(c) filter pencarian rumah kost

Gambar 9 merupakan tampilan aplikasi pada Customer melakukan pencarian rumah kost berdasarkan provinsi, nama ,alamat dan gambar rumah kost rumah kost berdasarkan provinsi yang di pilih. Pencarian rumah kost dapat menggunakan filter search seperti mencari berdasarkan nama, alamat, batas harga sewa, gender yang dapat menempati rumah kost, dan fasilitas yang dimiliki. Customer dapat melihat detail rumah kost seperti pada Gambar 10. 


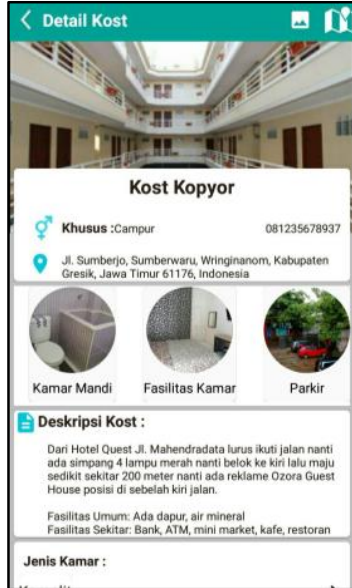

(a)

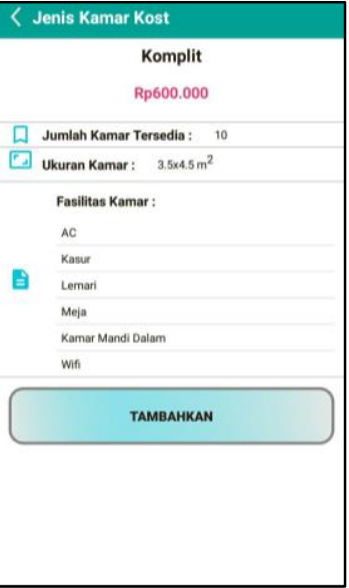

(b)

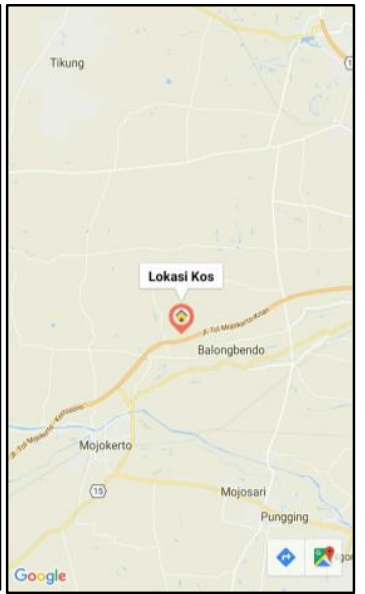

(c)

Gambar 10. (a) Tampilan Detail Rumah kost (b) Tampilan Detail Tipe Kamar Kost (c) Tampilan Lokasi Rumah Kost

Gambar 10 merupakan tampilan detail sewa rumah kost. Customer dapat melihat detail dari rumah kost seperti nama, alamat, gender yang dapat menyewa seperti khusus wanita, pria, atau campur (wanita dan pria), list koleksi gambar, deskripsi, dan tipe kamar yang tersedia. Tipe kamar memiliki detail seperti harga sewa, jumlah kamar yang tersedia, ukuran kamar, dan fasilitas kamar. Lokasi dari rumah kost dapat dilihat pada peta digital menggunakan Google Maps. Rumah kost yang ditambahkan dapat dilihat pada keranjang berserta dengan informasi nama kost, lama sewa, dan total harga sewa. Keranjang aplikasi berfungsi untuk dapat melakukan penyewaan rumah kost lebih dari satu. Customer yang telah memilih rumah kost yang disewa kemudian dapat melakukan penyewaan dengan memberikan bukti transfer biaya penyewaan. Gambar 11 merupakan tampilan halaman keranjang dan pemberian bukti pembayaran traksaksi penyewaan.

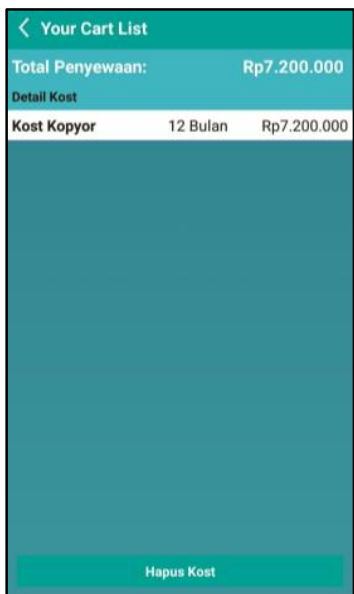

(a)

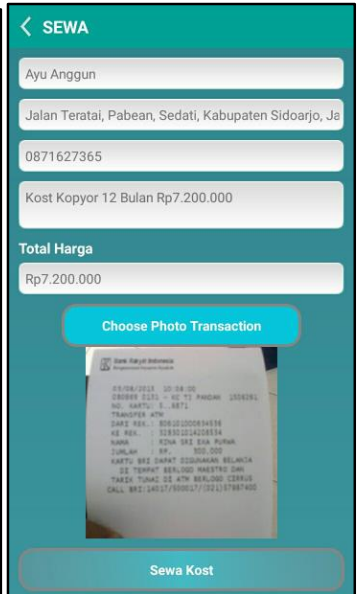

(b)

Gambar 11. (a) Tampilan Keranjang Penyewaan Kost

(b) Tampilan Pemberian Bukti Transfer Transaksi Penyewaan

Gambar 11 merupakan tampilan tagihan sewa customer. Admin melakukan pengecekan bukti transfer pembayaran sewa yang dilakukan oleh customer sesuai dengan tagihan yang diberikan. Tagihan yang telah sesusai dapat dilakukan konfirmasi oleh admin. Gambar 12 merupakan tampilan konfirmasi transaksi penyewaan yang dilakukan customer. Setelah mengirim bukti transfer, kemudian ditampilkan pada list transaksi dengan status "ON HOLD" yang berarti pemilik belum melakukan approve dan "Confirm" yang berarti pemilik telah melakukan approve. List transaksi dapat di lihat pada Gambar 12. 


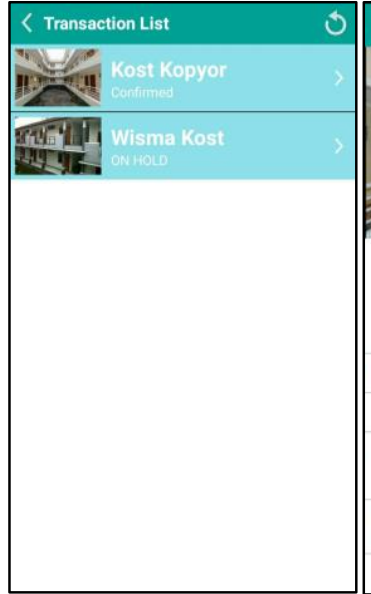

(a)

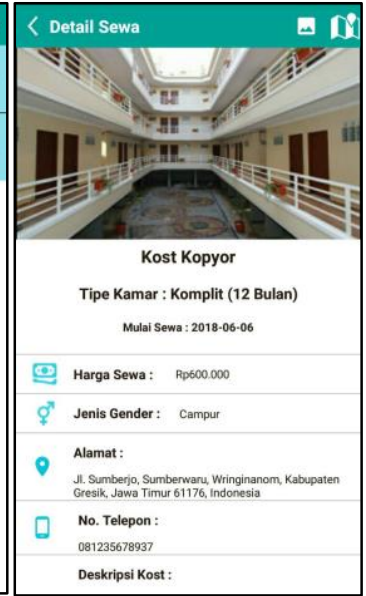

(b)

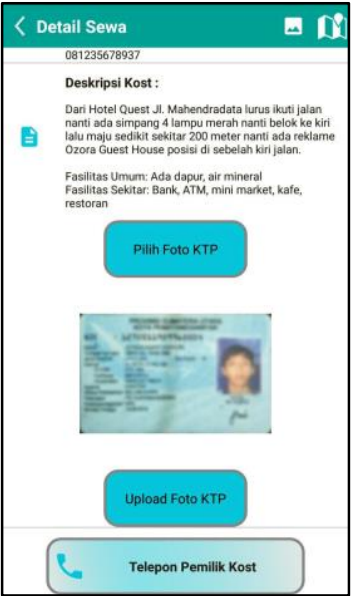

(c)

Gambar 12. (a) List Transaksi Kost Customer

(b) Detail Transaksi Penyewaan Rumah kost

(c) Upload Data Diri Penyewa Kost

Gambar 12 merupakan list transaksi sewa yang telah dilakukan customer dan dapat melihat melihat deskripsi rumah kost yang di sewa. pemilik dapat meminta customer melakukan upload data diri seperti KTP(Kartu Tanda Penduduk) dan customer menelpon pemilik.

\subsection{Admin}

Admin bertugas untuk melakukan konfirmasi pembayaran uang sewa oleh customer untuk melakukan pengecekan kesesuaian tagihan dan pembayaran yang dilakukan customer. Konfirmasi Admin dapat dilihat pada Gambar 13.

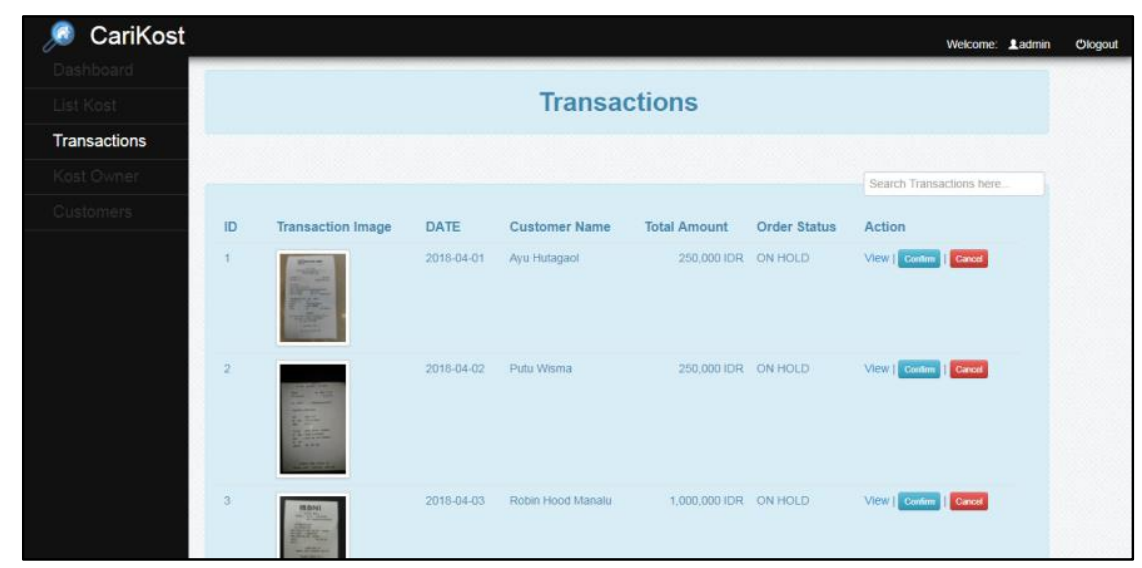

Gambar 13. Tampilan Halaman Konfirmasi Bukti Pembayaran Sewa

Gambar 13 merupakan validasi transaksi pembayaran sewa customer oleh admin. Transaksi yang telah dikonfirmasi oleh admin kemudian ditampilkan pada panel transaksi sewa pemilik rumah kost untuk melakukan proses approve.

\section{5}

\section{Kesimpulan}

Aplikasi pencarian dan penyewaan rumah kost merupakan sistem yang bersifat client dan server dimana Aplikasi client adalah pencari rumah kost yang merupakan pengguna aplikasi mobile Android dan Aplikasi server adalah admin sistem dan pemilik rumah kost meggunakan Web. Customer dapat melakukan pencarian dengan berbagai filter pencarian untuk mempermudah menemukan rumah kost yang diinginkan, penyewaan rumah kost dan dapat melihat detail transaksi sewa rumah kost yang telah disewa. Admin melakukan konfirmasi transaksi pembayaran sewa untuk disesuaikan dengan jumlah tagihan. Pemilik dapat menambahkan dan melakukan approve terhadap penyewaan rumah kost yang dimiliki 


\section{Daftar Pustaka}

[1] Setyoko. "Strategi Jasa Pemasaran Kos Wisma Niko di Tembalang." Obith. Vol. 10, No. $1,2014$.

[2] P. R. Andrian, I N. Piarsa, Ni K. A. Wirdiani. "Tree Method Implementation in Geographic Information System of Pura Kawitan in Bali Based on Android Mobile." International Journal of Computer Science Issues. Vol. 13, No. 4, 2016.

[3] I N. Piarsa, I Gde U. Putra, A. A. K. O. Sudana. "The Implementation of Tree Method in Geographic Information System of Mother Tample Mapping and its Linkages based on Web." International Journal of Computer Applications. Vol. 148, No.10, 2016.

[4] S. Rahayu, I N. Piarsa, and P. W Buana. "Sistem Informasi Geografis Pemetaan Daerah Aliran Sungai Berbasis Web." Lontar Komputer. Vol. 7, No. 2, 2016.

[5] S. A. Pratiwi, I M. Sukarsa, and I K. A. Purnawan."Rancang Bangun Aplikasi Pemesanan Bunga Berbasis Android." Merpati. Vol. 2, No. 2, 2014.

[6] L. G. S. Handayani, I N. Piarsa, K. S. Wibawa. "Sistem Informasi pemetaan Jalan Desa Bebasis Web." Lontar Komputer Vol. 6. No. 2, 2015

[7] D. Rosadi, F. O. Andriawan."Aplikasi Sistem Informasi Pencarian Tempat Kos di Kota Bandung Berbasis Android." Jurnal Computech \& Bisnis. Vol. 10. No. 1, 2016.

[8] J. Wibowo, M. Awaluddin, F. J. Ammarohman. "Pembuatan Basis Data Spasial Tempat Indekos Berbasis Web di Area Kampus Universitas Negeri Sebelas Maret." Jurnal Goedesi Undip, Vol. 6, No. 4, 2017.

[9] Gata, Windu \& Grace Gata. Sukses Membangun Aplikasi Penjualan dengan Java. Jakarta. Elex Media Komputindo. 2013.

[10] C. A. Pamungkas. Dasar Pemrograman Web dengan PHP. Yogyakarta. Deepublish. 2017.

[11] K. M. Wibowo, I. Kanedi, J. Jumadi. "Sistem Informasi Geografis (SIG) Menentukan Lokasi Pertambangan Batu Bara di Provinsi Bengkulu Berbasis Website." Jurnal Infotama. Vol. 11, No. 1, 2015

[12] B. Haryanto. Esensi-Esensi Bahasa Pemrograman Java. Bandung. Informatika. 2013. 